University of Louisville

ThinkIR: The University of Louisville's Institutional Repository

Electronic Theses and Dissertations

3-1949

\title{
Utilization of unwashed low grade phosphate rock.
}

Stanley Goldsmith 1924-

University of Louisville

Follow this and additional works at: https://ir.library.louisville.edu/etd

Part of the Chemical Engineering Commons

\section{Recommended Citation}

Goldsmith, Stanley 1924-, "Utilization of unwashed low grade phosphate rock." (1949). Electronic Theses and Dissertations. Paper 2040.

https://doi.org/10.18297/etd/2040

This Master's Thesis is brought to you for free and open access by ThinkIR: The University of Louisville's Institutional Repository. It has been accepted for inclusion in Electronic Theses and Dissertations by an authorized administrator of ThinkIR: The University of Louisville's Institutional Repository. This title appears here courtesy of the author, who has retained all other copyrights. For more information, please contact thinkir@louisville.edu. 
DWIVESITY CF LCUISVILIE

UTILIZATICN CF UNWASIED LCW GRADE FHCSFHATE RCCK

\author{
A Tho: 1 : \\ Submitted to the Faculty \\ of the Graduste sohool \\ of the University of Loulavi110 \\ in Partial Fulfiliment \\ of the Requirements \\ for the Degree of
}

MASTER CF CHENICAL ENO INEER ING

Stanley goldamith

haroh, 1949 


\section{UHE UNWvessir LIBRARIES}

This PDF document is a scanned copy of a paper manuscript housed in the University of Louisville (UofL) Libraries. The quality of this reproduction is greatly dependent upon the condition of the original paper copy. Indistinct print and poor quality illustrations are a direct reflection of the quality of materials that are available for scanning. The UofL Libraries greatly appreciates any better copies that can be made available for replacement scans. 
UTILIZATICN CF UNWASHBD LCW GRADE PHCSFHATE RCCK

Stanley coldamith

Approved by the Examining Comitter:

\begin{tabular}{ll} 
Director $\frac{\text { R. W. F. Morel }}{\frac{\text { R. C. Ernst }}{\text { G. C. Williams }}}$ \\
\hline W. R. Barnes \\
\hline
\end{tabular}

March, 1949 
CONTENTS

Page

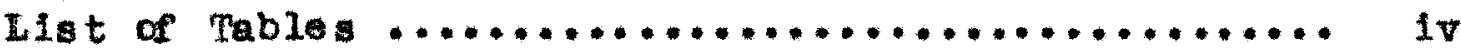

Acknowledgment $\ldots \ldots \ldots \ldots \ldots \ldots \ldots \ldots \ldots \ldots \ldots \ldots \ldots \ldots \ldots$

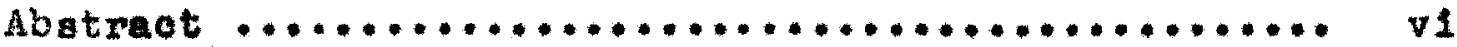

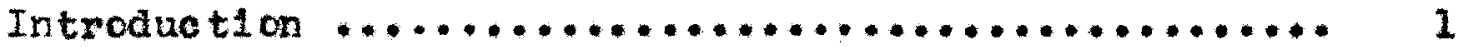

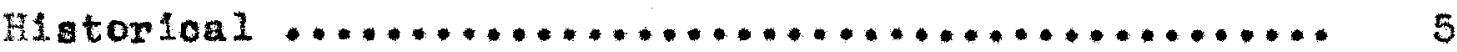

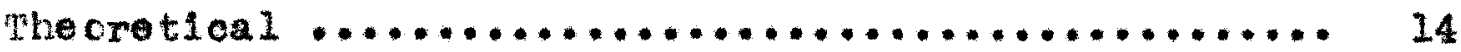

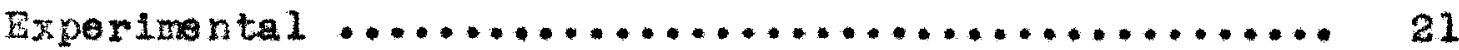

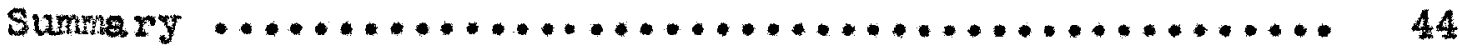

Ilterature c1ted .............................. 48

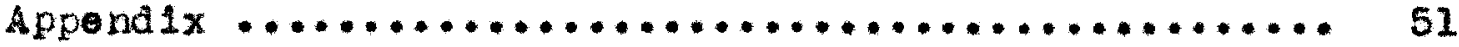

Acknowledgment $\ldots \ldots \ldots \ldots \ldots \ldots \ldots \ldots \ldots \ldots \ldots \ldots \ldots \ldots \ldots \ldots \ldots$

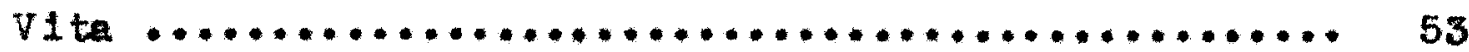


Fage

I Phosphe to Rock Wined in tho United States

II Analysis of thoaphate Pook Uaed In $\mathrm{H}_{3} \mathrm{PO}_{4}$ Production

III Raw Haterial, Power and Labor Requirenenta for thosphorle Acld production per ton of $100 \% \mathrm{H}_{3} \mathrm{PO}_{4}$

IV Analysis of Phosphato Rook No. 20

$V \quad$ Exploratory Run with Nitrio and Sulfurio Ac Id

VI Determination of Cptimum Conoentraticns and Amounts of $\mathrm{H}_{2} \mathrm{SO}_{4}$

VII Sulfurlo Acld Leaching at $75^{\circ} \mathrm{C}$

VIII Iron and Aluminum Reroval by pH Ad jus tmont

IX Fiemoval of Iron Jy Electrodeposition

$X$ Leaching of CaleIned No. 20 Fock 1 th $\mathrm{H}_{2} \mathrm{SO}_{4} \quad 35$

XI Conoentration of Crude Ehcaphorle Aald 37

XII Fomation of Iron and Aluminum Phosphatea 39

XIII Leaching of Fhosphate Rcck with solutions of $\mathrm{NaOH}$ and $\mathrm{Na}_{2} \mathrm{CO}_{3}$

XIV NaOH, $\mathrm{NaCl}, \mathrm{Na}_{2} \mathrm{CO}_{3}$, and $\mathrm{Na}_{2} \mathrm{SO}_{4}$ Fustons of Phospha to Rock 
ACLINWLEDGUENT

The author wishes to acknowledge

the kind assiatance and belpful guidance

of Mr.R. W. F. Morel

who directed this research 
A B S T R C T 
A nethed for the production of phosphorlo acta from Iow grade, unwashed phosphate rock by loaching with sulfurlo acld wa developed. Deteminaticns were made of the offects upon the acld-rook reaction of impurities in the rook, temrorature of reaction, concertration of aclas, amount of acld for complete reaction, and pre-treatment of rock. A phcaphorie acld of 25 per cent atrength was obtalned.

Mothod are described for the production of sodium phosphate by fusing or leaching phosphate rook with sodium carbonate, sodium hydroxide, scdium chicride, and sodium sulfate.

Defluorinetion of phosphat rook is performed by treating phosphato rock with sulfur at elevated temperatures. A defluorinated phosphete rock containing less than one por cent flucrine ia then obtained. 
INTECDOCTION 
Phosphete rock is classlfled as high, medium, or $10 \mathrm{w}$ grade, depending on its phosphorus content. High grade phosphate rook contains at least 32 por cent $\mathrm{P}_{2} \mathrm{O}_{5}$ (phosphorus pentoxide) and is used for the production of high grade phosphate fertllizers (2), and phosphoric acid by the wet proces $(2,3)$. Nodium grade rook contains 20 to 30 per cent $\mathrm{F}_{2} \mathrm{O}_{5}$ and Is used for the production of phosphorlo aold and phosphate chenlcals by the lectrio (4) and blast-furnace procosses (5), as well as for the preduction of phosphate fortilizers. Phosphate rcck contalning less than 20 per cent $\mathrm{P}_{2} \mathrm{O}_{5}$ la classifled as low Erade rcck, and as yet has not been put to any commerclat use.

It is usually recessery to benerlelate or up-grade the raw rock by elther flotation or water washing to obtain the phosphorcus oontent necessary for comercial use. The phosphate rock found in Florida and the Western atates can be beneflolated by flotation. This is not the case with the Tenressee phomphate rock. For the most part Tennessee rook can only be up-graded by water washing.

From technleal standpolnt, one of the most imporm tant and one of the most difficult of the problem facing the phosphe industry is the rooovery or elimination of the large quantities of phosphates which ro now lost during the mining and properation of pennessee phosphate rock for comercial use. These losses result, ossentlaliy, from the lnablilty to mechanically separate the phospate partioles from the undesirable 
impuritios such as allicon, 1ron, and aluminum compcunds (6). of equal importance is the utilization of low grade phosphate rock to replenlsh the deoreasing deposits of phosphate rock of aigh quality. This depletion of high quality phosphate rook is partlcularly notlcosble in the Tennesseo deposita.

The phosphate reserves of the United states are $23,286,700,000$ long tons (7), or 51 per cent of the werla's total. The rook mined in the united states in reoent years, a shown in Table $I(8)$ shows large inoreases in tonnage mined durlng the past fow years.

TABLE I. PHCSPHATE PCOK WTNE IN THE ONITED STATES (LCHG TONS)

Year

1934

1941

1943

1945

$$
\text { Florida }
$$

$2,464,969$

$3,417,900$

$3,274,266$

$3,814,935$

\begin{abstract}
Tennesseo
\end{abstract}
Western States

Total

$$
394,311
$$$$
38,958
$$

$2,898,238$

$1,301,067 \quad 201,876$

$4,920,843$

1,868,407 227,294

$5,369,967$

$1,260,849 \quad 323,955$

$5,399,739$

This rate of mining does not seer cause for alarm when the reserve are considered, but mining of Tennessee phosphate rock is decreasing. This decrease is a result of the depletion of high quality rock.

For most treatnents of Tennessee phosphate rock, it 1s usually necesary to up-grade the mined rock by wasing, to obtain the phosphorus content required. This wahing operation, 
whilo increasing the per cent phespherus, results in the $208 \mathrm{~s}$ cf 50 por cent of the phosphorus found in the original rook. The phosphcrus carried cf 1 th the wash water is in the form of a colloidal slupension, and as such also presents a serious disposal problom.

It is the purpose of this work to utllize low grade, unwahed phosphate rock for the produotion of phosphcric acid and phosphate chemicals. The work also includes the treatment of phosphate rook to yield preduct sultable for a cattle focd.

The bulk of phosphate rook 1 used for the production of phosphate fertilizer. Being material involving large quantitios of low unit value, fertillzer ha 1 t economio feasblilty dependert upon raw material costs. With low grade phosphate rook, it is not economioally practloal to manufacture a fertilizer to compete wh fertilizer made from higher Erade rook; ocngequently, 10 grade rock must bo used for manufacture of products other than fert111zers. Greater margin is provided betwoen seliline price and manucturing costs in the phosphate chemical fleld. This field orfers pessible means of utilizing poor grades of phosphate rook. 
HIS $\mathrm{H}$ O品ICAL 
Phosphorus was first 1 oolated by a German alchemist, Brandt (9), in 1669 , by distillation of urine. It was given

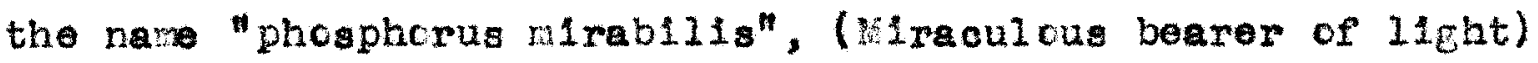
by the early alchemista (10). Cahn (11) discovered tho oxistonce of calclum phosphate ir bonos, but it was not until 1771, when scheele publishod this infomation, that phosphorus was cotainea from bone-ah.

Phosphoric acid was produced by Feadmar and coworkers in 1888 by an olectric process (11), which was the forerunner of the prosent day leotrle furnace process. Feadman, in 1890, alac propared phosphorle acld by treating bone-ash with auluric acla.

Unt11 1920, all of the phosphorle acid produced commercialiy was by the wet (sulfurie acid) method (12). The - lectric furnace prceas for phoshorio acla production wa a result of oxtensive experinontal vork carried on by the 0.5 . Bureau of ScI. $(13,14)$, and was developed on a commerclal scale by tho Eederal Phosphorus Company (6) in 1920 and 1921. Work carried on by the U. S. Bureau of solis was also irstrunental In the development of the blast furrace nethod of phosphoric acid production (15). Tho flr t commercial bla at furnace was bullt by the Vlotor Chemleal Works in 2828.

The wet method of phosphorlo acla production was renovated in 1936 by the introduction of the "Dorr-Strcng Acid Process" (16). Fecent developments by the Tennessee Valley Author1ty (5) on the blest furnace process has orabled this 
process to compete with the electrio furnace process o that ourrently there are three methods - wot, blast furnace, and - loctric furnace, employed for the production of phosphorio ac1d.

In the wet mothod (27) for produoing phosphcric acid, phosphate rock contalnzing 30-36 per cent $\mathrm{P}_{2} \mathrm{O}_{5}$, and relatively small amcunts of ircn, aluminum, and glilca is used. The rock is grcund wet wh wak phosphorle acld, and 60-650 Be' sulfuric acid is added a make-up acla for full aoldulaticn at higher acld trengthe. The sulfurio acld ocncentration in the mix is 30-350 Be'. Finely ercund limestcre is added to proc1pltate the iron and aluminum inpurities a the phosphates. The preclpltated impurftios and the unreacted rock are removed by mean of an ollver fliter. The flitered phosphoric acid is then passed to evapcrators where the cid is concentrated to 45-50 per cent phosphoric acid. The woak phosphoric acid which results from washing the filter cake is used to mix with the phosphate rcek belng ground and passes through the oomplote cycle again. Thl sesults in bullding up the concentration of phosphoric acid obtained from the sulfurlo acld-phosphate rook reaction.

The principlo employed in the electric furnace process for the production of phespheric acid is roduction of the phesphate rock followed by the volatilization of elonental phosphorus, oxidaticn of the phosphcrus, and subsequent hydration to fcrm phosphorlo acid (5). The phosphato rock used in the 
process containg between 24 and 32 per cent $\mathrm{F}_{2} \mathrm{O}_{5}$. The rock is sintered or nodulized to facilltate the escapo of phosphorus vapcrs (17). The sintered, cr ncdullzed, rock is charged into the furnece wth ccice and silfce sand. As the chare descends in the furnace shaft it is fused and the reduced phosphorus vaporized, carbon noncxide also beling liberated. Alr is passed In Ith the gases and the phosporus oxidized to $E_{2} O_{5}$. The ${ }_{2} 0_{5}$ is hydrated to produce an 35 per cent phosphoric acid. An alternative mothod used with this process is to ccol the gaser coming out of the furnace and collect the ecndensed phosphorus under water. This perits the carbon monoxide to be reccrered and used as a fuel gas. The condensed phosphorus can be sold as such or cxidized to $\mathrm{F}_{2} \mathrm{O}_{5}$ and bydratod to phosphoric acid. A by-product of the electric furnace is forrophcophorus which is arawn off with the slag. The glag itself can be used as ageregate for rcad construction or in concrote. As In the electric furnace process, the blast furnace process is based on the volatilization of elemental phosphorus. Th1s process uses phosphate rcok contalning 22 to 32 per cont $\mathrm{k}_{2} \mathrm{O}_{5}$; the process aotually favcring the rock having the lower $\mathrm{P}_{2} \mathrm{O}_{5}$ content $(5)$. In this process the rock is pulverized and mixed with ground coke. This mixture is conpressed into briquettes (17). The briquettes are aumped linto the top of the furnace alore with silioa. Hot air is passed into the furnaco and "blast furnace gas" contalning olemental phosphorus and carbon monoxide is liberated. This $8 \mathrm{~s}$ is pased through 
cyclone separatcrs to rencve any dust material that might be entrainod. The blast furnace gas is then ignited to form $\mathrm{CO}_{2}$ and $\mathrm{P}_{2} \mathrm{O}_{5}$ and the heat of combustion 18 used in the hot blast stoves to produce hot blast air. The $\mathrm{F}_{2} \mathrm{O}_{5}$ is converted direotly to 85 per cent phosphoric acld. A valuable by-product from this process 1s ferrophosphorus which passes out with the slag. Recent work done by the Tennessee Valley Authority cn the blast furnace process has eliminated the briquetting of the phosphate rook and ooke. The Tennesseo Valley Authority hes also developed a mothod of preferentially oxidizing the blast furnace gas (phosphoru and carben monoxide) so that all of the phosphorus is converted to $\mathrm{I}_{2} \mathrm{O}_{5}$ and practically nono of the carbon monoxide is oxldized. This allows the carbon monoxide to bo used as a fuel gar. It is expocted that this development w111 rejuvenate the blast furnace process. Typloal analyses of the phosphate rocks used in the wet (3), oloctric furnaco (18), and blat furnace processes (5) are shown in Table II.

Table III (7) gives the raw material, power, and labor requirements of the three different motheds of phosphorto acid production. It should be ncted that these requirements are based on a resultant phosphorle aold strength of 46.5 per cent $f \circ r$ the wet procesa, 85 por cent for the loctric furnace, and 100 per cent for the bla furnaco. From these tables it can be seen that the two furnace processes not only use a 10 wer quality rock than the wot process but alsc yield a highly pure product. A faotor in favor of the wet process is the small 
cyclone separators to remove any dust material that might bo entrained. The bla at furnece gas is then ignited to form $\mathrm{CO}_{2}$ and $\mathrm{P}_{2} \mathrm{O}_{5}$ and the heat of combustion $1 \mathrm{~s}$ used in the hot blast stoves to produce hot blast alr. The $\mathrm{P}_{2} \mathrm{O}_{5}$ is converted direotly to 85 per cent phosphoric acid. A valuable by-product from this process is ferrophosphorus which passes out with the slag. Recent work done by the Tonnessee Valley Authority on the blast furnace process has eliminated the briquetting of the phoshate rock and coke. The Tennessee Valley Authority has a lso developed a method of preferentially oxlaling the blast furnace gas (phosphorus and carbon monoxide) sc that all of the phosphorus is c cnverted to $\mathrm{P}_{2} \mathrm{O}_{5}$ and practioally none of the carbon moncxide is oxldized. This allows the carbon moncxido to be used as a fuel gas. It is expected that this development w11l rejuvenate the blast furnace prooss. Typlcal analyoes of the phosphate rocks used in the wot (3), electrio furnace (18), and blast furnace processes (5) are shown in Tabie II.

Table III (7) gives the raw torial, power, and labor requirements of the three different method of phophorle acld production. It should be noted that these requil rements are basod on a product of 100 por cent phosphoric acid. strengths of phosphoric acid produced by the wet, electrio furrace, and blast furnace are $46.5,85$ and 100 per cent, rospoctively. From these tables it can be seen that the two furnace processes not only use a lower quality rock than the wet process but also yield a highly pure product. An important factor in faver of the wet process is the small 
TABIE II. ANALYSIS CF LEOSFEATE FCCK USE IN $\mathrm{H}_{3} \mathrm{PO}_{4}$ RRCDONION

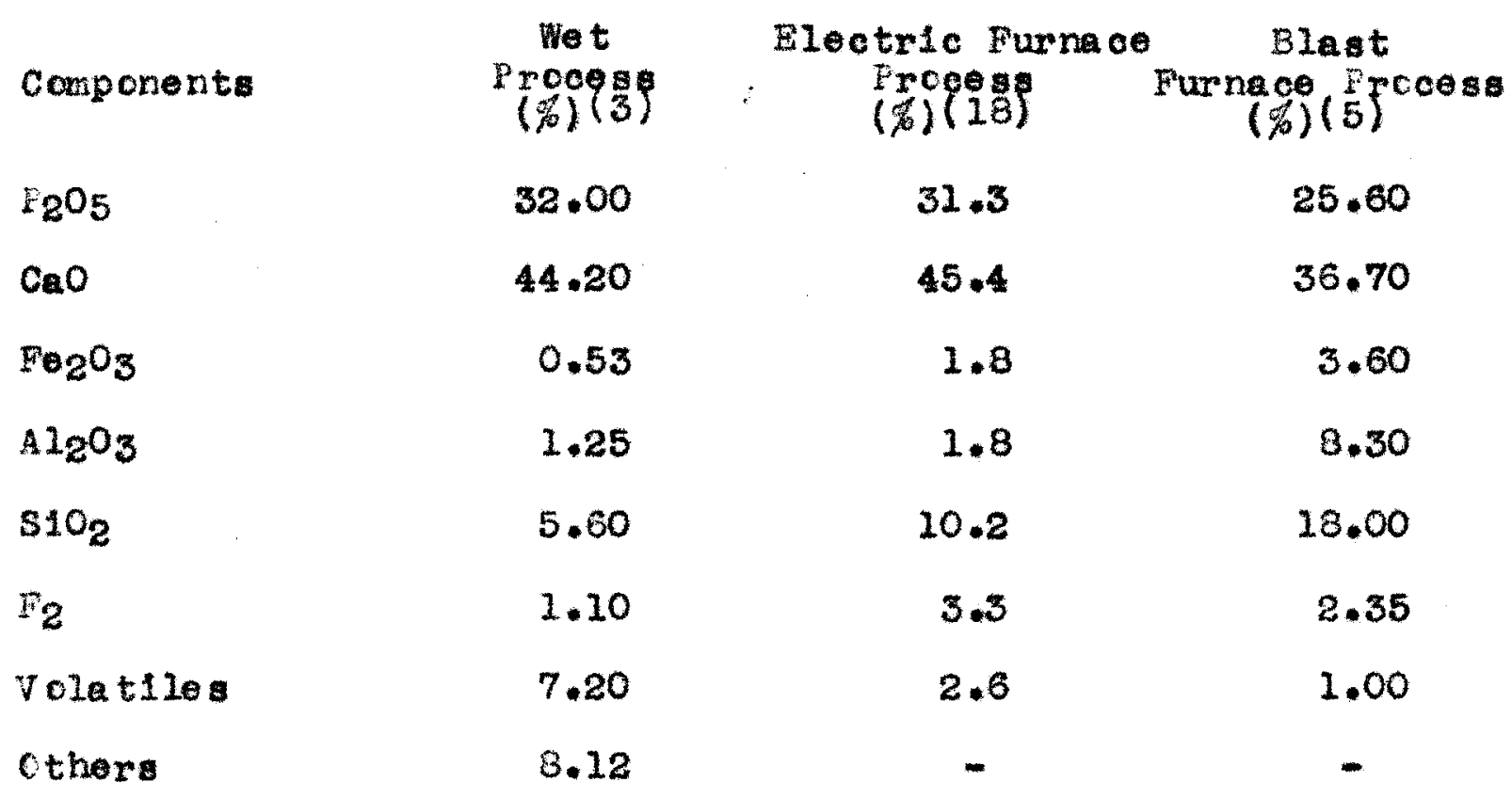


TABLE III. RAW MATHIALS, FOWE, AND LABOF TEQUIFEDENTS FCR $\mathrm{H}_{3} \mathrm{PO}_{4}$ ERODUCTICT $\mathrm{FER}$ TCN CF $100 \% \mathrm{H}_{3} \mathrm{PO}_{4}$

$\begin{array}{llc}\text { Wet Process } & \begin{array}{l}\text { Electric } \\ \text { Furnace }\end{array} & \text { Furat } \\ \text { Process } & \text { Process }\end{array}$

Strength of Acid (f)

Fhos pha to Rock (Ibs.)

Sulfurlo Aold (10s*)

Water (galso)

Steam (1ba.)

Eloctricity (iv-hre.)

Diroct Labor (man hrs.)

S1110a Rook (10se)

Coke (108.)

Air $(c u * f t)$

$$
\begin{gathered}
46.5 \\
5,050(a) \\
4,190 \\
16,130(\mathrm{c}) \\
1,678
\end{gathered}
$$$$
112.9
$$$$
1.7
$$$$
-
$$$$
-
$$$$
-
$$

85

$4,670(a)$

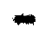

$-$

-

4,060

$0.6-1.12$

2-4

1,493

1,500

880

7,000

450,000

(a) $32 \% 2 \mathrm{O}_{5}$

(b) $27 \% \mathrm{P}_{2} \mathrm{O}_{5}$

(c) Chlef $2 y$ for cooline

(d) For cottreli preolp1tators on $1 y$ 
Initial cost of the equipment and cheapness of raw materials. Alsc, only gmall power or fuel requirements are neded. The economic feasibility of the electric furnace process depends on cheap scurce of olectricity. This is nct the case with the blast furnace method but it requires relatively largo amounts of coke and water.

Cf the phosphate chomicals produced for chemical use, trisodium phosphate is the most important (19). The Industrial importance of trisodium phosphate is due in part to 1ts propertios of hydrolyzing il. water sciution to $\mathrm{g}$ ive a high pH clution well buffered against noutralization ard it ablitty to easily form soft and eranular proclpitate with heavy motal Lens, guch as magroalum, Iron, aluminum, and calclum. Because of these properties, trisodium phosphate hes been used extensively as a water sof tener (17).

Intensive researoh durlne the past decade on the alkall metal salts of the varlous phosphoric acids has resulted in the development of new and ocmerclally useful sodium phosphate salts $(20)$. Of the sodium phosphates recontly doveloped, scdlum metaphosphate, sodiun tripolyphosphate, scdium pyrophosphate, and sodium orthophosphate are of the most importance industrially. The Hall Laboratcries (2l) have been instrumental In the adaptation of these salts for water conditioners. Many grazing ranges in the United States are so depleted of avalable phosphorus that cattle grazine on the se ranges have a phophorus defieleney. As a supplemental scurce 
of phosphorus, defluorinated phosphate rook has boen found very setisfactory (22). Because of the toxiolty of fluorine, it is necessary that its prosence in phosphatlo materialo used as cattlo focd be los than four-tenthe of one per cent.

Fox and his associatos (23) removed 80 to 99 per cent of the fluorine prosent in superphosphate by heating for a oomparatively shert period of time at $600^{\circ} \mathrm{C}$ or above. The resultant tricalcium phosphate compared favorably with bone mol as minoral supploment for oattlo foed.

Elmore (24) olaims total removal of fluorine from phosphate rook by fusing at temperatures of $1600^{\circ} \mathrm{C}$. Fhcsphat rock has been 95 per cent deflucrinated by wcrkers at T.V.A. (25) by heating the rock until molton, usually to $1450-1600^{\circ} \mathrm{C}$. lio montion $1 \mathrm{f}$ found anywhere in the literature of deflucrination of phosphate rook at temperatures below $1000^{\circ} \mathrm{C}$.

The prominent role played by the Tennessee Valley Authority in the development of the phosphorie aold and phosphate industry warrants pecial mention in review of the history of this industry. References to work done by the T.V.A. appear throughout this section. The T.V.A. has performed, and 1s performing, a great number of exporiments at the pllot plant level whlch heve, and w111, holp the phosphate Industry as a whole $(26-30)$.

These brlefly-ment loned developnent and proosses of the phosphate industry do not, of course, include all of the activities of the industry. They do serve, however, to show the current trend of the phosphate industry. 
THE ORE TICA 
Tenresseo phosphate rcek occurs for the most part in Silurian and Devonian strata. Fost of the rook is found in tho silurian strata and in the trangition strata between the twe. The brown rook lies in strata formaticn with layers of clay and earth overburden (31). Phosphate rcck is an apatito cre "which mey be of orgaric crigin but the more extengive bedad depcatto probably represent chemical procipitates of merine crigin and variable purity. Fosldual depcstes have boen fornod by phosphatic Imestcro boing leached of the ${ }^{2}$ lime carbcrate" (32). The reaction of apatite with sulfuric aclo, depending on the ancunt of sulfuric acid usod, car ylold monocalolum phosphate, diealcium phosphate, and phosphoric acld, togothor wth calcium sulfete and unreacted calchum flucride. The reactions can be written as follows:

$$
\begin{aligned}
& \mathrm{Ca}_{2} \cdot 3 \mathrm{Ca}_{3}\left(\mathrm{PO}_{4}\right)_{2}+3 \mathrm{H}_{2} \mathrm{SO}_{4}-6 \mathrm{CaHPO}_{4}+3 \mathrm{CaSO}_{4}+\mathrm{CaF} 2 \\
& 6 \mathrm{CaHFO}_{4}+3 \mathrm{H}_{2} \mathrm{SO}_{4}=3 \mathrm{Ca}\left(\mathrm{H}_{2} \mathrm{PO}_{4}\right)_{2}+3 \mathrm{CaSO}_{4} \\
& \mathrm{Ca}\left(\mathrm{H}_{2} \mathrm{PO}_{4}\right)_{2}+\mathrm{H}_{2} \mathrm{SO}_{4}=2 \mathrm{H}_{3} \mathrm{FO}_{4}+3 \mathrm{CaSO}_{4} \\
& \mathrm{Ca} 2+\mathrm{H}_{2} \mathrm{SO}_{4}=\mathrm{H}_{2} \mathrm{Fa}_{2}+\mathrm{CaSO}_{4}
\end{aligned}
$$

with an excess amount of sulfuric acid, all phosphates will corvert in time to phoshoric acid so that the reaction of aptite with excess ulfuric acld can be written appoximately as:

$$
\mathrm{Ca}_{3}\left(\mathrm{PO}_{4}\right)_{2}+3 \mathrm{H}_{2} \mathrm{SO}_{4}-3 \mathrm{CaSO}_{4}+2 \mathrm{H}_{3} \mathrm{PO}_{4}
$$

Wth less than the requirod amount of suifuric acid, a mixture or $\mathrm{CaHPO}_{4}, \mathrm{Ca}\left(\mathrm{H}_{2} \mathrm{PO}_{4}\right)_{2}$, and $\mathrm{H}_{3} \mathrm{HO}_{4}$ is possible.

In a phosphate-bearing rcck there are cther constituonts, doscribed as impurities, besides apatite which will react 
with the sulfurio acld or ctherwise affect the reaction. Foremost ancre these Impuritles are ircn, aluminum, silicon, and calelum (as the carborate). Iron and aluminum conpounds may react with sulfurle acld to produce soluble sulfates. S1110cn, as sillca, for the most part aces not roact with sulfuric acid. Calcium carbonate frrm insoluble calclum sulfate when acted upon by sulfurio actd.

From the foregclne, it can be seen that the phosphoric acla produced by the wet prccess must be treated to remeve irch and aluminum impuritio before a flnal preduct can be obteinod. A slight recuction in the aclaty of the phosphoric acld favors the precipltation of ferrcus iron and aluminum as the phosphates. The romal of forrous 1 con and of a luminum results in the $10 \mathrm{~s}$ of twothirds of an atomic wolght of phosphorus, or two atcmic welghts, deponding on the procipltate form, for overy atomic weight of ferrous iron and ono atomio welght of phosphorus for every atomic wolght of aluminum present as impurities. Ferric iron form soluble complexes in the presence of excess phosphoric scid, and cannot bo removed in this menrer. Effoctively, for every atcmic weitht of ferric iron prosent in solution one atcmic wolght of phosphoru is tied up. The above 1 shown in the following simplified equations:

$$
\begin{aligned}
& 3 \mathrm{FOSO}_{4}+2 \mathrm{H}_{3} \mathrm{PO}_{4}=\mathrm{FO}\left(\mathrm{FO}_{4}\right)_{2}+3 \mathrm{H}_{2} \mathrm{SO}_{4} \\
& \mathrm{FoSO}_{4}+2 \mathrm{H}_{3} \mathrm{PO}_{4}=\mathrm{FO}\left(\mathrm{H}_{2} \mathrm{FO}_{4}\right)_{2}+\mathrm{F}_{2} \mathrm{SO}_{4} \\
& \mathrm{Al}_{2}\left(\mathrm{SO}_{4}\right)_{3}+2 \mathrm{H}_{3} \mathrm{PO}_{4}=2 \mathrm{AIPO} \mathrm{P}_{4}+3 \mathrm{H}_{2} \mathrm{SO}_{4} \\
& \mathrm{FO}_{2}\left(\mathrm{SO}_{4}\right)_{3}+2 \mathrm{H}_{3} \mathrm{PO}_{4}=2 \mathrm{FPO}_{4}+3 \mathrm{H}_{2} \mathrm{SO}_{4}
\end{aligned}
$$


The above reactions take place as the pH of the sclution 1o raised. The fron phospha to ha been observed to preoipltate at pll as low as 2 . The aluminum phosphate begins to precipltate at alightly bigher pH.

There is rason to believe that calcination of phosphate rcok tend to suppress to a certain oxtent the formation of a soluble 1ron or a luminum phosphate, wi thout affecting the conversion of calosum phosphate to phcsphoric acid. Such calcination would result in the formation of iron and aluminum compound relatively inert when acted upon by alfurle acid. The stolohiometric or thecretical amount of alfuric acid for aciduiation is a flctiticus vaiue, besed on the amount of aulfuric acid required to react with the calcium, lron, and aluminum oxides in the rcok. This value, however, is very uaeful as a basis on which to report results. The need for suoh a bals can readily be seen when it is roalized that the phosphate in the rook is present not only as calclum phosphate but also as the iron and aluminum phosphates.

Phosphate rock can bo defluorinated by heating until a molten stage is reached $\left(14500^{\circ}\right.$.). Phosphate rock o cntaining high percentages of iron and aluminum oxide (10\%) along with - lilica can be doflucrinated nost easily, as thoso materials aot as luxing agents (25). Waximum defluorination is obtained at a silca-1ime ratio of 0.38 . As the silica-11me ratio increases abowe 0.38 , the thickness of the orust on the melt Increases, decreasing efficiency of deflucrination. A furnace atmosphero 
of nitrogen and water vapor cnly is ossentlal for good defluorination. At temperature of $1500^{\circ} \mathrm{C}$ the per cent of water vapor In the furnace atrospheres betweon 2 and 40 per cent has very 11tt le fifect on deflucrination. At a temperature of $1600^{\circ} \mathrm{C}$ this is not the case. The per cent fluorine removed increases as per cont water vapor in atmosphere increases.

Working with 5 to 40 gram oharges of phosphate rook, heated in platinum-rhodium bcats in a high temperature tube furnace, Elmore, Huffman, and yolf coveloped the following general equations to desoribe defluorination of phosphate rock as a restance phencmena:

$$
\begin{aligned}
& \frac{1}{\mathrm{X}}=\frac{0.038 \mathrm{~d}}{\mathrm{~d}}+\frac{0.359 \mathrm{~d}^{2}}{\mathrm{D}} \\
& \text { Where } \frac{1}{\mathrm{~K}}=\text { total resistance to deflucrination, } \\
& \text { a - depth of charge in cen, } \\
& \text { W and } D=\text { constante for a given composition at con- } \\
& 0.988 \mathrm{~d}=\text { resiatance to deflucrination the surface, } \\
& \begin{aligned}
\frac{0.359 \mathrm{~d} 2}{D}= & \text { resistance to deflucriration due to diffu- } \\
& \text { sion in the melt. }
\end{aligned}
\end{aligned}
$$

Doflucrination of phosphate rock can be cbtained by the pasage of steam and sulfur dioxide gas over the rook during calcination. The sulfur dioxide probably displaces the fluorine in the flucrapatite and the presence of steam rosults in the formation of hydrogen flucride. The hydrogen flucride, regardess of the sweeplne action of the gas stream would react with the allica in the rock to $f 0 \mathrm{rm}$ slifcor tetrafluoride. The 
probable reactione taking place at $10000 \mathrm{C}$ are shown in the following simplifiod oquations:

$$
\begin{aligned}
& \mathrm{CaF}_{2}+\mathrm{H}_{2} \mathrm{O}+\mathrm{SO}_{2}=\mathrm{CaSO}_{3}+2 \mathrm{HF} \\
& 4 \mathrm{HF}+\mathrm{S1O}_{2}=\mathrm{SIF}_{4}+2 \mathrm{H}_{2} \mathrm{O}
\end{aligned}
$$

In this method of defluorination of phosphate rook, as In practically all of the other nethods, tricalcium phosphate is formed, which is a scurce of readily avallable phophcrus. Triscdium phosphate, $\mathrm{Na}_{3} \mathrm{FO}_{4}$, is the most widely used compound of the phosphates. Its wethod of preparation 1 s carried out in two stepa. Scdium carbonate is treated with phosphoric acid to yleld discdium phosphate. The discdium phosphate is treated with odium hydroxide to give trisodium phosphate. These reactions shown in the follewing equations:

$$
\begin{aligned}
& \mathrm{Na}_{2} \mathrm{CO}_{3}+\mathrm{H}_{3} \mathrm{PO}_{4}=\mathrm{Na}_{2} \mathrm{HPO}_{4}+\mathrm{CO}_{2}+\mathrm{H}_{2} \mathrm{O} \\
& \mathrm{Na}_{2} \mathrm{HPO}_{4}+\mathrm{NaOH}=\mathrm{Na}_{3} \mathrm{PO}_{4}+\mathrm{H}_{2} \mathrm{O}
\end{aligned}
$$

Proposed processes for triscdium phosphe manufecture include thermal one, In which soda ash or caustio soda is fused wh apatite; and also a wet prooes, in which finely Eround apati to is Iixiviated with caustic Iiquors. Triscdium phosphate has also been produced by sintering, in a rotary kin, a mixture of finely ground ferrophosphorus and ada ash in the presence of air. The soluble triscdium phosphate is removed from the sinter by leaching wh water.

Sodlum salts of meta- and pyrophosphoric acld have been produced and $f$ cr the most part can be looked upon as moloculariy dehydrated form of the sodlum orthophosphates. 
Sodium wetaphosphate can be prepared by any one of the following reacticns:

$$
\begin{aligned}
& \mathrm{NaH}_{2} \mathrm{PO}_{4}+\mathrm{Heat}=\mathrm{NaPO}_{3}+\mathrm{H}_{2} \mathrm{O} \\
& \mathrm{Na}_{3} \mathrm{PO}_{4}+\mathrm{r}_{2} \mathrm{O}_{5}=3 \mathrm{NaFO}_{3} \\
& \mathrm{NaCl}+\mathrm{HrO}_{3}=\mathrm{NaPO}_{3}+\mathrm{HCl}
\end{aligned}
$$

Scdium pyrcphosphate is prepared by hetine discdium phosphate atiown fn the following reaction:

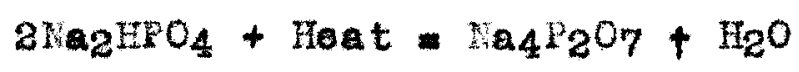

Converting the phosphates present in phosphate rook to phosphates of sodium would result in a mothod of ealiy extracting phosphoru from the rock. 
EX P E I 
The purpose of the experimental work perfomed as part of this Investigetion is the reclamation of phosphorus from unwashed, 10w grade phoophate rock. Nethods for the production of phosphoric acid, phosphato chenioals, and defiuorinated phosphato rock are develcped.

The phosphate rock used in this investigation is a Tennessee brown rock which has been ground to a fineness of minus 100 meah. The rcok recelved no treatment after being mined, other than that of drylng and grinding, and was obtained at Rlaley, Tennesseo. This reck i. Idertifled as "No. 20 Rook". Its anelysis $1 \mathrm{~g}$ given in Table IV. In thio table is also glven the sulfuric acid requirements based on the amounts of calcium, iron, ard aluminum cxide present. The "etolchlometrio" or "theoretical" amounts of sulfuric acld required to glve complete roaction $1 \mathrm{~s}$ shown a 77.25 grams por 100 grams of rook. Two wethcds, "volumetr10" and apetrophotonotrio, were employed for phosphorus analyals. In most instances, analyses were made by both methods. Designation is made In the presentation of the data as to the methods used.

The volumetric procedure consists essentially of first precipltating the dissolved phosphates as amonium phosphomolybdato, after which the preclpitato is disecived in a standard caustic olution. The oxcess caustio is then titrated with a standard acld solution. The phosphorus percentage, reported as $\mathrm{P}_{2} \mathrm{O}_{5}$, $1 \mathrm{~s}$ calculated from the volumes of atandard sclution used. A ecmplete detalied description of this method 
TABLE IV. ANALYSIS CF PHCSHEATE FCCK NC. 20

A. Book Analysis : *

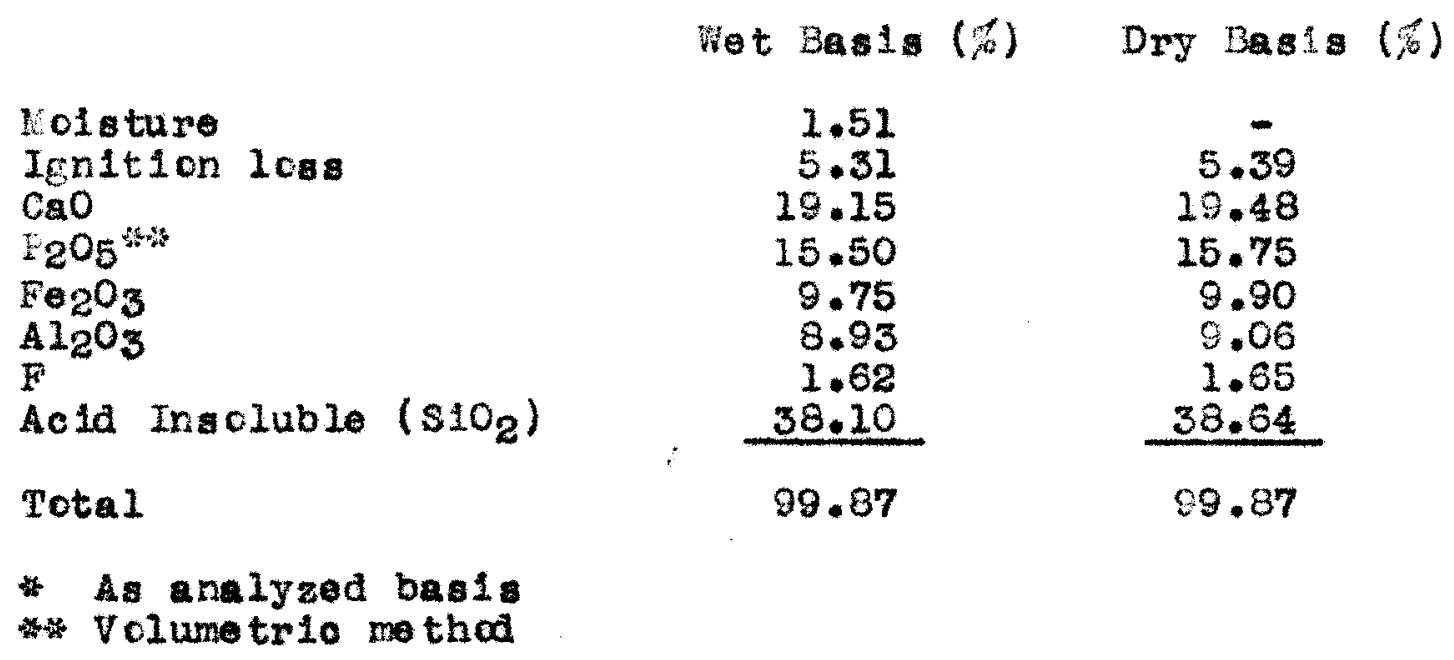

B. Sulfuria Acld Requirements for Phesphoric Acld for 100 Grams Fock, 1.51\% of a ture:

Constituents $\mathrm{H}_{2} \mathrm{SO}_{4}$ Required $(\mathrm{g} \cdot)$

$\mathrm{CaO}$
$\mathrm{Al}_{2} \mathrm{O}_{3}$
$\mathrm{Fe}_{2} \mathrm{O}_{3}$

Total
33.60

25.70

17.95

77.25

C. Proximate Rock Analyaia (Dry Basis):

$\mathrm{CaCO}_{3}$

Apatite

$\mathrm{AlFO}_{4}$

$\mathrm{Al}_{2} \mathrm{O}_{3}^{* *}$

$\mathrm{Fe}_{2} \mathrm{O}^{*}$

Aeld Insoluble $\left(\mathrm{SiO}_{2}\right)$

Total

* Corablned as olicates
Fer cent

$$
\begin{array}{r}
11.93 \\
23.61 \\
11.06 \\
4.05 \\
9.90 \\
38.65 \\
\hline 100.00
\end{array}
$$


may bo found in "Offlolal and Tentative Methods of Analysis of the Assoolation of Cfficial Agrioultural Chemists" (33).

In the speotrophotometric mothod, the sample to be analyzed is dissolved and reacted with solution containing sodium molybdate and hydraz ine sulfate to fcm hoteropoly complex compounds of phosphorus. The heteropoly complex compcunds are reduced, reaulting in a blue-colored solution. The transmit tancy of the solution wes determined In a Beokman Model DU sectrophotometer. From the per cont of light transitted through the olution, the per cent of the phoaphorus an be caloulated (34).

The thod used to analyze for fron and aluminum is completely desoribed in "Comerolal Nethods of Analysin" by snoll and Biffen (35). The method consista esentially of precipltatine fron and alumirum as the phosphate in the presence of ammonium acotate and acetic acid. The precipitate is transferred to weighed crucible and IEnited to the pyrophesphato and weighed. The pyrophosphates are fused with scdium carbonate and the nolt disclved in sulfurto sola. This solution is then passed thrcugh a Jones reductor and titrated with standard potassium pormenganate. The amount of 1 ren and a luminum can then be calculated from the welghts of pyrophosphates and the vclume of potosalum permanganate used.

The analyses for flucrine were nade by adding sulfuric acld and silica to the samplo and steam distiling. The fluorine is volatilized as $\mathrm{H}_{2} \mathrm{~S}_{2} \mathrm{~F}_{6}$ and collected in the 
distilate. The distillato is titrated with a sandard thorium nitrate sclution, using zirconium alizarin sulfonate an indicatcr. The per cent flucrine is then calculated from the amount of thorlut nftrato used for titration (36). Work on the production of phosphorio acid 1 rom phosphate rock was perfomed by loaching 100 grams of rook wh th acid. The general prooedure followed in all leachlng runs was to place the desired ancunt of ackd in a 600 mililiter boaker ard odd the weighed amount of rook tc the acld with agltation. The mixture was atirred ontinuousiy throughout the run (4 hours) by mean of an elootric atirrer. After four hours, the un reacted rock wa filtered of by vacuun flitration and washod with water. The unrocted rock was analyzod for phosphorus. The filtrate (crude phosphorio acid) was analyzed for phosphorus, Iron, and aluminum.

The flrst aries of leaching rune made were exploratcry in nature and were made to determine the relative merits of sulfuric and nitric acids as loching agonts. Runs 101, 102, and 107 were made using a 20 per cent $\mathrm{P}_{2} \mathrm{O}_{5}$, unwashed rook (Nic. 2U) as this was the cnly rock avallable at the time. Witric acid was used in runs 101 and 102 and sulfurlc ac1d was used in rung 207 and 109 . The rock used in run 109 was "No. 20 Rock" contalning $15.5 \% \mathrm{P}_{2} \mathrm{O}_{5}$. Equivalent amount of acid were used in all cases. In these four rung analyses wero only made for phosphorus, reported as $\mathrm{P}_{2} \mathrm{O}_{5}$. From the results cbtained, a shown in Table $V$, nitric acid offerod no advantage over 
TABLE V. EXELCRATORY PUNS WITH NITRIC AND SULEURIC ACID

\begin{tabular}{|c|c|c|c|c|c|}
\hline Run $\mathrm{N}$ & Wo. & 101 & 202 & 107 & 109 \\
\hline Reck: & $\mathrm{NC}$ & 20 & 20 & 20 & 20 \\
\hline & $w t \cdot\left(\varepsilon_{*}\right)$ & 100 & 100 & 100 & 100 \\
\hline & $\mathrm{E}_{2} \mathrm{O}_{5}(\mathrm{z})$ & 20.0 & 20.0 & 20.0 & 15.5 \\
\hline Acid: & : Kind & $\mathrm{HNO}_{3}$ & $\mathrm{ENO}_{3}$ & $\mathrm{H}_{2} \mathrm{SO}_{4}$ & $\mathrm{H}_{2} \mathrm{SO}_{4}$ \\
\hline & Cone. $\left({ }^{\circ} \mathrm{Be}^{\prime}\right)$ & 25.0 & 30.0 & 22.8 & 35.0 \\
\hline & Cone. $(x)$ & 35.0 & 42.0 & 26.0 & 41.3 \\
\hline & wt. $(\mathrm{g} \cdot)$ & 335.0 & 270.0 & 269.0 & 187.0 \\
\hline & The oretical $(z)$ & 100 & 100 & 100 & 100 \\
\hline $\mathrm{P}_{2} \mathrm{O}_{5}$ & Extracted: Oram & 10.80 & 17.25 & 14.45 & 13.24 \\
\hline & 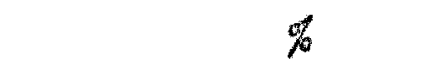 & 54,00 & 86.20 & 72.25 & 85.50 \\
\hline
\end{tabular}


sulfuric acid. Since sulfurio acld was the lo as expersive of the two, it was deolded to use sulfurio acld in all the leaching runs that rollow.

Following the decision to use sulfurlo acld for leaching, a series of runs were rade to determine the optimum concentration and anount of sulfuric acld to be used. A reviow of the data tabulated in Tablo VI shows variation in the total amounte (amount in filtrate plus amount of rosidue) of phosphorus, 1ron, and luminum. Aftor chocking and rechecking the ara Iysis, it was found that these variations were due to the non-uniformity of the rook as usod. The two mothods of analysia used, volumetric and spetrophotcmetrie, check fairly well in analyzing the filtrate. The results obtalned by the spectrophotcmetric mothod are slightly lower than by the volumetric nethod, the latter boing affected by the large sulfate concontration. In the residue analysis, a larger varlation is obtained with the two methed, the volumetric method giving higher results. Thls is due to the larger percentage of sillca present in the residue. The pectrometrio method is considered to be moro accurate as this mothod is not aubject to as many possible surces of interference as is the volumetric method. Jary Ing the concentration of acid from $35^{\circ}$ to $50^{\circ} \mathrm{Be}$ and the amounts of acld between 90 and 132 per cent of theoret1cal required had no apreclable effect on the amount of phosphorus remowed from the rock. There was a difference of approximate 10 pent in the amounts of 1 ren and aluminum extractod. The amount of 1 ron and a luminum extracted wa 
TABLE VI. DETEFMTEATICN OF CETIMUM CCNCENTPATICI AND AHCUNTS OF SULEURTC ACID

Run Ro.

$$
110 \quad 111 \quad 112 \quad 113 \quad 114
$$

Sulfurle Acla:

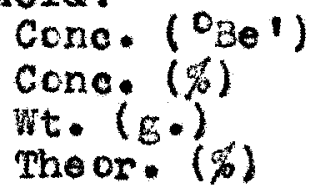

wt. of Rosidue (E•)

Filtrate: Vol. (ml.)

Sp. Gr.

$\mathrm{P}_{2} \mathrm{O}_{5}$ Analyois ( $\left.\mathrm{V} 02 \cdot\right)(\mathrm{g} \cdot)$

Filtreto

Residue

Total

$\mathrm{P}_{2} \mathrm{O}_{5}$ Extracted (\%)

P2O5 Anal. (speot.) $\left(g_{*}\right):$

Plitrato

Fosidue

Total

1205 Extraoted ( $\%)$

$\mathrm{Fe}_{2} \mathrm{O}_{3}$ Analysis (e) :

Filtrate

Feslatue

$\mathrm{Fo}_{2} \mathrm{O}_{3}$ Extractou $(\vec{p})$
$W_{t} \cdot\left(g_{*}\right)$

Total

$\begin{array}{rrrrr}22.8 & 35.0 & 35.0 & 50.0 & 50.0 \\ 26.0 & 41.3 & 41.3 & 62.2 & 62.2 \\ 297.0 & 246.5 & 187.0 & 124.0 & 112.5 \\ 100 & 132 & 100 & 100 & 90\end{array}$

$\begin{array}{lllll}107.7 & 106.5 & 108.3 & 206.9 & 107.0\end{array}$

$\begin{array}{lllll}575 & 360 & 387 & 438 & 400\end{array}$

$\begin{array}{lllll}622.6 & 414.5 & 432.3 & 485.5 & 437.7\end{array}$

$\begin{array}{lllll}1.090 & 1.173 & 1.133 & 1.119 & 1.120\end{array}$

$\begin{array}{rrrrr}12.40 & 13.28 & 14.07 & 14.13 & 14.24 \\ 6.72 & 3.31 & 2.47 & 2.89 & 2.76 \\ 18.12 & 16.59 & 17.04 & 17.02 & 17.00 \\ 64.0 & 80.0 & 82.5 & 33.0 & 83.8\end{array}$

$\begin{array}{ccccc}12.22 & 13.30 & 13.24 & 13.65 & 13.68 \\ 5.41 & 2.21 & 1.94 & 1.87 & 2.27 \\ 17.63 & 15.51 & 15.23 & 15.52 & 15.95 \\ 69.3 & 85.7 & 87.0 & 88.0 & 85.8\end{array}$

$\begin{array}{rrrrr}4.10 & 4.58 & 4.63 & 4.62 & 3.96 \\ 4.58 & 4.11 & 4.35 & 4.42 & 4.55 \\ 8.68 & 8.69 & 8.98 & 9.04 & 8.51 \\ 47.2 & 52.8 & 51.5 & 51.7 & 43.4\end{array}$

$\mathrm{Al}_{2} \mathrm{O}_{3}$ Analysis (E.):

Filtrate

Realdue

Total

$\mathrm{Al}_{2} \mathrm{O}_{3}$ Extracted (\%)

$\begin{array}{lrrrr}4.26 & 5.27 & 5.73 & 4.21 & 4.03 \\ 4.60 & 4.16 & 4.50 & 4.74 & 5.08 \\ 8.86 & 9.43 & 10.23 & 8.95 & 9.11 \\ 48.1 & 35.9 & 56.0 & 47.1 & 44.2\end{array}$

Note: For a 11 runs, 100 E. No. 20 rock used, Temperature $20-25^{\circ} \mathrm{C}$, Time 4 hours 
approximately 50 per cent of the orlginal anounte in the rock. The change of 10 per cent at this high percontage in the amount extracted dces not alter the problem of lron and aluminum removal to any extent. In view of this, the percentage iron and a luminum extracted was ocnsidered of seocndary importanco in determining the optimum amount and concentration of sulfurio acld to be used. Uaing concentrations of sulfuric acta above $500 \mathrm{Be}$ did not Elve suffiolont fluldity to the mix to give complete reaction. Because of this deorease in fluldity at higher concentrations, the lower concentrations were considered the most generally satiafactcry.

In the runs presented in Table VI, difficultios wero exporienced in filtexing the mix. A serles of rune wero made to determine the effect of temperature on the filtering oharetorlstics of the mix and the general bohavior of the roaction. A temperature of $75^{\circ} \mathrm{C}$ was ueed for the se runs to asist in Eypaum crystal growth. Thlo temperature was taken as appor IImit, because at temperatures of $1000 \mathrm{c}$ and abcve, Eypsum dehydrates. The dehydration of Eypsun to form anhyarito would 1ncrease filtering difficultes. A constant tomperature was naintalned by placing the beaker in whioh the reaction took place in constant temperature bath. A study was also made In these rune to determine the maximum ooncentration of phosphorus cbtainable in the f1ltrate at maximum extraction. Where varying concentrations and amounts of acld wore employed, the volume of the flnel filtrate (crude phosphoric acid) and not 
the volume of wash water used, must be used as a criteria. The flitering rate was alightly improved due to the agelcmeration of calcium sulfate at a reaction temperature of $75^{\circ} \mathrm{C}$. A review of the results in Table VII show that the tomperature does not affect appreciably the extraction of phosphorua from phosphate rook (Run 115).

Run 116 was made, usirig only the sulfuric acid requirementy for reacticn with $\mathrm{CaO}$ and $\mathrm{Al}_{2} \mathrm{O}_{3}(59.3$ grame of $100 \%$ aufuric acid) to deterine if preferential reaction would take place. The mount of Iron extracted was eseertially the same as in runs using $100 \%$ of theoretieal amount 177.3 grams of $100 \%$ sulfuric acia) of alfuric acid.

A study of the results obtained te this point revealed that varying the conditions of leaching silghtiy improved filtering conditions but did not lower the por cent of iron and aluminum extracted. Two nethod were tried to remove the Impuritios (1ron and aluminum) appering in the crude phosphoric acid. The first nothcd was the usual nothco used for removal of 1 ron and aluminum from phosphoric acid; $1.0 .$, pH adjustment. From the resulte shown in Table VIII, it can be seen that ali the Iron and luminum was removed fron solution as the phosphate. Since such high percentages of Iron and aluminum are present in olution, their preclpltation as the phosphates loaves very ittle phosphorus in solution. Phis rethod is not a foasible way to remove iron and aluminum. The sucond method, eleotrodepostion, was used to 
TABLE VII. SULURIC ACD LEACHTNG AT $75^{\circ} \mathrm{C}$

Run No.

Sulfurlo Acto:

Cone. ( $\mathrm{OBe}$ ')

Cone $(\%)$

wt. $(g$.

Thecretical (

wt. of Residue $(\varepsilon \cdot)$

Vol. of Filtrate (ml.)

$\mathrm{P}_{2} \mathrm{O}_{5}$ Anelyais $(\mathrm{E} \cdot)(\mathrm{Vclum}$ tric): Fil trato

les ldue

Total

$\mathrm{P}_{2} \mathrm{O}_{5}$ Extracted (

Fos Analysis $(\mathrm{g} \cdot)$ (spoctro.):

Filtrate

Fesidue

Total

$\mathrm{F}_{2} \mathrm{O}_{5}$ Extracted $(\%)$

$\mathrm{F}_{2} \mathrm{O}_{3}$ analyas $(\mathrm{g} \cdot)$ :

Filtrato

Rosidue

Total

$\mathrm{Fe}_{2} \mathrm{O}_{3}$ Extracted $(\%)$

$\mathrm{Al}_{2} \mathrm{O}_{3}$ Analysis $(\mathrm{g} \cdot)$ :

Filtrate

Residue

Total

$\mathrm{Al}_{2} \mathrm{O}_{3}$ Extracted (
115

116

117

$\begin{array}{rrr}50 & 30 & 30 \\ 62.2 & 34.6 & 34.6 \\ 124.0 & 172.0 & 222.0 \\ 100.0 & 77.0 & 100.0\end{array}$

$\therefore \quad 115.1$

213.2

125.1

285.0

112.4

98.5

16.31

9.00

7.73

16.73

53.8

18.34

84.4

15.52

8.93

7.18
7.60
9.90
17.50
43.4
2.18

17.70

87.80
7.44

2.42

9.86

75.40

7.87

1.66

9.53

82.60
4.22

4.46

8.68

48.60 
TABLE VIII. IRC AND ALUNINUU PEMCVAT BX PH ADJUSTRENT

Run No.

$1.10-5$

W1. taken from gun 110 iltrate for treatment

100

* $\mathrm{F}_{2} \mathrm{O5}$ in filtrate $\left(\mathrm{E}_{*}\right)$

$2 \cdot 345$

pH of elitrate

$<1$

pH at which preolpitate first forned

$1-2$

11. $10 \%$ aclution of $\mathrm{Na}_{2} \mathrm{CO}_{3}$ added to ra1se $\mathrm{pH}$ to 4.5

107

Wolght of precipltate $\left(E_{*}\right)$

$5 \cdot 5$

Volume of filtrate (mi.)

207

ForOs in filtrate $(g \cdot)$

Tr.

${ }^{4} 2 O_{3}$ in filtrate $(8$.

Tr.

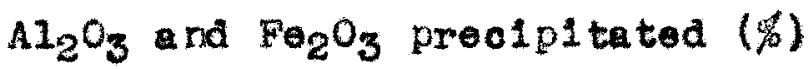

$99^{4}$

$\mathrm{P}_{2} \mathrm{O}_{5}$ romaining in alution (\%)

10.12

* Based on orleinal velume cf filtrate in fun $110-575 \mathrm{ml}$. spectrophotonetrie methed uead. 
remove only the fron from solution. A moderate current densty was employed and both lron and aluminum cathodes were used separately. A source of direct current was obtained frcm a $1 x$ volt battory, using varlablo resistcr to maintaln the dosirod amperage. Semoval of iron should result in an inorease in welght of the cathode. Table IX acws that, saentially, no we 1 ght change of the cathcde cocurred; hence no iron was removed fren the solution.

Wo chemical methcd could bo found or developed for the separation of Iron and a luminum from phosphorus when the thres ocour in the proportions obtalned in the filtrates. In view of this, tests were made to determine the effects of pretreating the rook before leaching. These tests were also made to further aliorate filtering conditions. Calcination of fered a relatively inexpensive and aimple method of pretreatment. The reck was caleined in a muffle furnace at $900-1000^{\circ} \mathrm{C}$, and resulted In a 7.8 per cent decrease in weight. It was found, as shown in Table $X$, that calcining the rock before treating with acid not cnly out down on the iron extractod but also changed the nature of the preolplate in such mannor that filtration was very rapid. The concentration of eulfuric acld used was $30^{\circ} \mathrm{Be}$ which gave a aix having fluidity of a highly satiafactory nature. Numerically in milillters the volume of filtrate was appoximately twice the welght in grams of the residue. Cptimum extraction and concentration of phosphorus wore obtained under the se conditions. 
TABLE IX. FERCVAL OF IRCN BY ELECTRCDEPCSITICN

$\begin{array}{lll} & \begin{array}{c}\text { Iron } \\ \text { Cathode }\end{array} & \begin{array}{c}\text { Aluminum } \\ \text { Cathode }\end{array} \\ \text { Current Denalty (ampa/sq. ft.) } & 20 & 20 \\ \text { Ancde } & \text { Lead } & \text { Lead } \\ \text { Current used (amps.) } & 2.93 & 1.18 \\ \text { Time of } 5 \text { lating (min.) } & 30 & 30 \\ \text { Inltlal welght of cathode (g.) } & 26.6821 & 6.0374 \\ \text { Weight of cathode after plating } & 26.8742 & 6.0324\end{array}$

Note: Filtrate from Run 114 used. 
TABLE $x$. LEACHIHG OF CALCINED NO. $20 \mathrm{ROCK}$ WITH $\mathrm{H}_{2} \mathrm{SO}_{4}$

Run No.

118

Initial weight of rook $(g *)$

100.0

Calolning Temperature $\left(\mathrm{O}^{\circ}\right)$

$900-1000$

Calolning Tine (hrs.)

3

Wolght of rock after calcining $\left(g_{*}\right)$

$92 \cdot 2$

We lght of $\mathrm{H}_{2} \mathrm{SO}_{4}$ used $\mathrm{for}$ leaching $(\mathrm{g} \cdot)$

222.0

Concentration of $\mathrm{H}_{2} \mathrm{SO}_{4}\left(\mathrm{OBO}^{\prime}\right)$

30

Time of leaching (hrs.)

4

Temperature of loeching $\left({ }^{\circ} \mathrm{C}\right)$

75

Volume of Filtrate (ml.)

200

Weight of ressdue $(\mathrm{g} \cdot)$

108.3

$\mathrm{F}_{2} \mathrm{O}_{5}$ Analyais $\left(E_{*}\right)$ : Realdue*

2.35

Filtrate*

11.16

rotal

23.51

$\mathrm{P}_{2} \mathrm{O}_{5}$ Extracted $(\not / \%)$

82.50

$\mathrm{Fe}_{2} \mathrm{O}_{3}$ Analysis (g.): Reslave Filtra to

5.01

3.02

Total

8.03

$\mathrm{Fe}_{2} \mathrm{O}_{3}$ Extracted $(\%)$

37.60

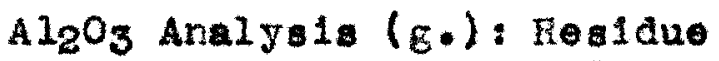

3.57

Filtrato

3.07

Total

6.64

$\mathrm{Al}_{2} \mathrm{O}_{3}$ Extracted $(\$)$

53.75

* Spootrophotometrio Vethod 
The ooncentrations of the crude phosphoric acid as obtained in the filtrate was between 5 and 10 per cent $\mathrm{F}_{2} \mathrm{O}_{5}$. A serles of testa were made to determine to what etrength the crude phosphorio aold could be ccncentrated. Concentration was carried on by evaporation, nct allowing the temperature to exceed $150^{\circ} \mathrm{C}$ at ang time. At temperature above $150^{\circ} \mathrm{C}$, the orthophosphoric acld is converted to pyrophesphoric acid. The results of these concentration tests are shown in Table XI. For these teots, 1000 gram of rook were leached with slightly less than the thecretical amount of $300 \mathrm{Be}$ ' sulfurfo acla, to produce the crude phosphorio acld.

Crude phosphoric acid can be concontrated to 25 per cent $\mathrm{H}_{3} \mathrm{FO}_{4}$ by evaporation of water at temperatures belcw $150^{\circ} \mathrm{C}$. No evaporation takes place at or below temperatures of $150^{\circ} \mathrm{C}$ when the strength of the acid reaches 25 per cent $\mathrm{H}_{3} \mathrm{PO}_{4}$. During concentration lron and a luminum phosphates crystallized out acocralng to their solubilities in phosphoric acla.

The data shown in Table XI bears out the conclusion that maxum extraction of phophorua from the rock is not cbtalned unloss the volume (in ml.) filterod is substantially greater than the welght (In grans) of the rosidue. It is of interest to note that, in splte of the differences in amounts of phosphorus extracted, the oncentration of phosphcrus in the filtrete is ossentialiy the same.

Since the crude phosphorlc acld obtained by sulfurlo aold leaching of rook contalned relatively large mounts of 
TABLE XI. CCNCEHTRATIC CF CFUDE PHOSFHCRIC ACID

\section{Leaching}

Inftial welght of ro. 20 rook $(\mathrm{E} \cdot)$

Caloination Temperature $\left({ }^{\circ} \mathrm{C}\right)$

Calcination Time (brs*)

Welght of rcok aftor calcination (

Welght of $30^{\circ} \mathrm{Be}^{\prime} \mathrm{H}_{2} \mathrm{SO}_{4}(\mathrm{E} \cdot)$

Temperature of Leaching $\left({ }^{\circ} \mathrm{C}\right)$

Wolght of Plitrate (a)

volume of Filtrate (mi.)

Welght of Restave $(\mathrm{g} \cdot)$

Wolght of $\mathrm{F}_{2} \mathrm{O}_{5}$ in Filtrate $\left(\mathrm{g}_{\bullet}\right)(1)$

$\mathrm{P}_{2} \mathrm{O}_{5}$ Extracted $(\%)(2)$

$\mathrm{P}_{2} \mathrm{O}_{5}$ in Filtrate $(\%)(3)$

Concentration

Volume of Filtrate after cone. (ml.)

welght of Filtrate after Cone. (g*)

Welght of $\mathrm{F}_{2} \mathrm{O}_{5}$ in Ccno. Filtrate $(\mathrm{g} \cdot)^{(1)}$

$\mathrm{P}_{2} \mathrm{O}_{5}$ in Conc. Filtrate $(\%)(3)$

$\mathrm{H}_{3} \mathrm{PO}_{4}$ in cono. Filtrate $(\%)(3)$

$\begin{array}{cc}\text { Run 127 } & \text { Run 133 } \\ 1000 & 1000 \\ 900-1000 & 900-1000 \\ 3 & 3 \\ 922 & 922 \\ 2000 & 2000 \\ 75 & 75 \\ 1072 & 1450 \\ 825 & 1132 \\ 1012 & 1015 \\ 78.6 & 101.88 \\ 52.5 & 67.8 \\ 7.33 & 7.02\end{array}$

142

143

252

263

$45.44 \quad 47.7$

$18.00 \quad 18.15$

24.85

25.05

(1) By spoctrophotometrio Method

(2) Based on $15.6 \% \mathrm{~F}_{2} \mathrm{O}_{5}$ content of rook

(3) Weight bais: 
Iron and a luminum, a possibility of producing iron or aluminum phosphate from the orude acid existed. The crude phosphorio aold was saturated with lron flings in an attempt to bring dcwn a relatively pure iron phosphate. The game procedure was used with aluminum powier in an ettempt to bring oown aluminum phosphate. Any phosphates which would be precipitated would be reflected by a decrease of phosphorus in the solution. The results of four runs are tabulated in Table $Y I I$, and show that Iron or aluminum phosphates canpot be produced in this manner. Leachings of phosphate rook were made olutions of sodium hydroxide and sodium carbcnate to produce sodium phoephate directly from the rook. The procedurs followed was the same as that in making sulfurio acld lochings. Caloined rock was used. As can readliy bo seen from the data in rable XIII, this process offers no pronise whatgcever.

A second methed of foming acdium phosphete was tried. This method coneists of fusine phosphate rock with ocdum salts or Wh sodium hydroxide. The fused mas was ground and then leached with water to remove the water soluble scdium phosphates formod. The insclubles wore then fllterod off and the leach 11quor analyzed for phosphorus. The result of these fusions are shown in Table XIV. Fualng phosphate rock with sodium carbonate and wh sodium hydroxide does show ome promlse for producing sodium phosphates, but the eocnomy of this process whon such low extractions are cbtained makes its practicability hichly questionable. 
TABLE XII. FCRWATCN CF IFCN ANO ALUWINUW PHCSPHATES

\begin{tabular}{|c|c|c|c|c|}
\hline & $\begin{array}{l}\text { Run } \\
131\end{array}$ & $\begin{array}{l}\text { Fun } \\
136\end{array}$ & $\begin{array}{l}\text { Run } \\
132\end{array}$ & $\begin{array}{l}\text { Run } \\
135\end{array}$ \\
\hline Volume of sclution used $(\mathrm{ml})$ & 100 & 50 & 100 & 50 \\
\hline $\mathrm{P}_{2} \mathrm{O}_{5}$ criginaliy in solution $(\mathrm{E} \cdot)$ & 3.22 & 1.71 & 3.12 & 1.71 \\
\hline We1ght of Iron added $(\mathrm{g} \cdot)$ & 1.28 & 2.00 & & \\
\hline Welght of Aluminum added $(\mathrm{g} \cdot)$ & & & 2.79 & 2.00 \\
\hline $\mathrm{P}_{2} \mathrm{O}_{5}$ remaining in solution $\left(\mathrm{g}_{*}\right)^{3}$ & 3.05 & 1.68 & 3.15 & 1.82 \\
\hline
\end{tabular}

* By spectrophotometric Method 
TABLE XIII. LEACHING OF PHOSPHATE TOCK WITH SOLUTICNS OF NAOH AMD $\mathrm{NACO}_{3}$

$\begin{array}{llll}\text { Run } & \text { Run } & \text { Run } & \text { Run } \\ 119 & 128 & 120 & 121\end{array}$

\begin{tabular}{|c|c|c|c|c|}
\hline $\begin{array}{l}\text { Inftial we leht } \\
\text { of Pook }(\mathrm{g} .)\end{array}$ & 50 & 100 & 50 & 50 \\
\hline Leaohing Agent & MaOH & IaOH & $\mathrm{Na}_{2} \mathrm{CO}_{3}$ & $\mathrm{Na}_{2} \mathrm{CO}_{3}$ \\
\hline $\begin{array}{l}\text { wt of Loaohing } \\
\text { Agent } 100 \%(E) .)\end{array}$ & 8.5 & 36.6 & 16.5 & 33 \\
\hline $\begin{array}{l}\text { Vol. of Lonching } \\
\text { Agent (mi.) }\end{array}$ & 50 & 130 & 136 & 272 \\
\hline $\begin{array}{l}\text { Str. of Leaching } \\
\text { Solution }(\%)\end{array}$ & 15 & 22.5 & 10 & 10 \\
\hline $\begin{array}{l}\text { \& of Theorettical } \\
\text { Required }\end{array}$ & 65 & 137 & 100 & 200 \\
\hline $\begin{array}{c}\text { Temperature of } \\
\text { Leaching }(\mathrm{OC})\end{array}$ & $20-25$ & $20-25$ & 75 & 75 \\
\hline $\begin{array}{l}\text { Tine of Leaching } \\
\text { (brs.) }\end{array}$ & 4 & 4 & 4 & 4 \\
\hline Wt. of Feslaue $\left(g_{*}\right)$ & 48.1 & & 48.0 & 46 \\
\hline Vel. of F1ltrato & 244 & 303 & 207 & 304 \\
\hline $\mathrm{F}_{2} \mathrm{O}_{5}$ in Filtrato & $0.823(b)$ & $2.06(0)$ & $0.178(\mathrm{~b})$ & $0.146(b)$ \\
\hline $\mathrm{P}_{2} \mathrm{O}_{(\mathrm{V})}$ Extracted $(\mathrm{d})$ & 10.6 & 13.30 & 2.95 & 1.88 \\
\hline
\end{tabular}

(a) Calc. amount necesary to convert $\mathrm{P}_{2} \mathrm{O}_{5}$ in rook to $\mathrm{Na}_{3} \mathrm{PO}_{4}$

(b) By volumetric thod

(c) BY Spectrophotometric Kethod

(d) Based on $15.5 \% \mathrm{~F}_{2} \mathrm{O}_{5}$ in Rook 
TABLE XIV. HaOH, $\mathrm{NaCl}_{2} \mathrm{CO}_{3}$ and $\mathrm{Ha}_{2} \mathrm{SO}_{4}$ FUSICNS CF ERCSHATE ROCK

\begin{tabular}{|c|c|c|c|c|c|}
\hline & $\begin{array}{r}\mathrm{Ne}_{2} \mathrm{CO}_{3} \\
\text { Run } 122\end{array}$ & $\begin{array}{r}\operatorname{Me}_{2} \mathrm{CO}_{3} \\
\text { Fun } 124\end{array}$ & $\begin{array}{r}\mathrm{Na}_{2} \mathrm{SO}_{4} \\
\text { Run } 125\end{array}$ & $\begin{array}{c}\text { NaCl } \\
\text { Fun } 126\end{array}$ & $\begin{array}{c}\text { NaOH } \\
\text { Run } 129\end{array}$ \\
\hline The of $\mathrm{Rcok}\left(\varepsilon_{*}\right)$ & 10 & 10 & 10 & 10 & 20 \\
\hline $\begin{array}{l}\text { Time of Fusion } \\
(\text { hrse) }\end{array}$ & 1 & 1 & 1 & 1 & 2 \\
\hline $\begin{array}{l}\text { Wt. of Fuging } \\
\text { Agent }(g \cdot)\end{array}$ & 5 & 10 & 10 & 10 & 7.32 \\
\hline $\begin{array}{l}\text { Yol. of } \mathrm{H}_{2} \mathrm{O} \text { used } \\
\text { for Leaching } \\
\text { (mi.) }\end{array}$ & 100 & 100 & 200 & 100 & 130 \\
\hline Temp. of Leaching & 75 & 75 & 75 & 75 & 75 \\
\hline $\begin{array}{l}\text { wt. of } \mathrm{r}_{2} \mathrm{O}_{5} \text { in } \\
\text { Leach Liquor }(E \cdot)\end{array}$ & $0.305(a)$ & $0.452(a)$ & Trace & None & $0.802^{(b)}$ \\
\hline $\begin{array}{l}\mathrm{P}_{2} \mathrm{O}_{5} \text { Extracted from } \\
\mathrm{Rock}\left(\mathrm{P}_{0}\right)(\mathrm{o})\end{array}$ & $19 \cdot 2$ & 29.2 & - & 0 & 25.8 \\
\hline
\end{tabular}


Deflucrinated phosphate rock was produced by hoating a mixture of phosphate rook and sulfur. Two mothods wero used for defluorination. The first method, used in runs 106 and 108 In Table XV, conslats of putting a mixture of sulfur and rook In a cruolble and heating to $1000^{\circ} \mathrm{C}$ for one to three hours. The seoond method, used in runs 134,137 , and 139 in Table XV, employs the "flash roasting" prinoiple. The rooksulfur rixture is injooted into the conter of a gas flame by introducing the mixture into the bumer with the primary air. This methad dces not give as ocmplete defluorination of the raveradoes the first method, the roason boing that flamo temperature above $750^{\circ} \mathrm{C}$ could not be obtained. There is every indication to believe that at comparable temperatures, the "flash roating" methed wculd bo superior to the oruclblo mothod. An added advantage of the flash roatine nethod is the shcrt time needed for defluorination. Both of these methods wil produce a rook containing less than one per cent fluorine. 
TABLE XV. DEFLUCFINATION CF FHOSFHATE FCCK

\begin{tabular}{|c|c|c|c|c|c|c|c|c|c|c|}
\hline & $\underset{106-A}{\text { Run }}$ & $\operatorname{Fun}_{106-B}$ & $\operatorname{Run}_{108-A}$ & $\underset{108-B}{\text { Fun }}$ & $\underset{134-A}{\text { Run }}$ & $\operatorname{Run}_{134-B}$ & $\begin{array}{c}\text { Run } \\
137-A\end{array}$ & $\begin{array}{c}\text { Run } \\
137-B\end{array}$ & $\underset{139-A}{\operatorname{Run}}$ & $\underset{139-B}{\text { Run }}$ \\
\hline$\left(\begin{array}{lll}\text { Wt. } \\
(\mathrm{g} \cdot)\end{array}\right.$ & 20 & 20 & 20 & 20 & 50 & 50 & 50 & 50 & 50 & 50 \\
\hline No. of Rock & 20 & 20 & $2 U$ & 20 & 20 & 20 & F3 & 53 & 20 & 20 \\
\hline $\begin{array}{l}\text { Fluorine in } \\
\text { Rock orig } \cdot(\%)\end{array}$ & 6.21 & 6.21 & 6.21 & 6.21 & 1.63 & 1.63 & 3.71 & 3.71 & 6.21 & 6.21 \\
\hline$\frac{\left.w t_{*}\right)}{\left(g_{*}\right)}$ of Sulfur & 1 & 1 & 2 & 2 & 1 & 2.5 & 1 & 2.5 & 1 & 2.5 \\
\hline $\begin{array}{l}\text { Sulfur in } \\
\text { ix. }\end{array}$ & 5 & 5 & 10 & 10 & 2 & 5 & 2 & 5 & 2 & 5 \\
\hline $\begin{array}{l}\text { Temp. Wuffle } \\
\text { Furnace }(00)\end{array}$ & 1000 & 1000 & 1000 & 1000 & & & & & & \\
\hline $\begin{array}{l}\text { Temp: Burner } \\
\text { Flare }\left(\mathrm{O}^{\mathrm{C})}\right.\end{array}$ & & & & & $\begin{array}{l}700- \\
750\end{array}$ & $\begin{array}{l}700- \\
750\end{array}$ & $\begin{array}{l}700- \\
750\end{array}$ & $\begin{array}{l}700- \\
750\end{array}$ & $\begin{array}{l}700- \\
750\end{array}$ & $\begin{array}{l}700- \\
750\end{array}$ \\
\hline $\begin{array}{l}\text { Time of Rum } \\
\text { (Nins.) }\end{array}$ & 180 & 60 & 60 & 180 & 15 & 20 & 15 & 15 & 15 & 15 \\
\hline $\begin{array}{l}\text { Fluorine fom. } \\
\text { in Fook }(\bar{Y})\end{array}$ & 1.780 & 0.741 & 0.801 & 1.24 & 1.02 & 0.55 & 1.40 & 1.36 & 2.20 & 1.40 \\
\hline
\end{tabular}


SUU A I 
Loach1ng of unwashed, 1 ow grade, Tennesseo brom phosphate rock with sulfurlo acld glelded a phosphoric acld which could be concentrated to 25 por cent $\mathrm{H}_{3} \mathrm{PO}_{4}$. Frotrating the rock by calcination at $900-1000^{\circ} \mathrm{C}$ before acldulation resulted in a depression of the amount of iron extracted and aso increased the rate of filtration.

The phosphate rock was ground to fineness of at least 100 mesh. Th1s inenoss insured intimate contact between the acid and the rock* :

Chomically, tomperature had no appreclablo effoot on the nature of the reacticn botween phosphate rock. Temperature did influenoe the reaction phylicalis. If the reaction took place at temperatures below $50^{\circ} \mathrm{C}$, the oalclum sulfate was In the form of very fine crystals that were alfficult to filter. Temperatures of approximatoly $75^{\circ} \mathrm{C}$ caused agglomeration of the calclum sulfate which facilitated filtration. Temperatures of approximately $100^{\circ} \mathrm{C}$ dehydrated gypsum so that there was an Inorease in filtering aiffloultios.

The strength of the requitred ulfurlc acld was influenced by the resulting fiuidity of the mix. This did not present a problem w1th higher grades of rock, as In commereial production, ince the ratio of olid to liquor wa much lower. In the reacticn between the dry rock and stolchlometric amount of sulfuric acla, the acld had to be diluted to at loast 500Be'. For a roaction time of four hours, varying the concentration of oulfurio acld between 30 and $500 \mathrm{Be}$ ', did not effect the 
amount of phosphorus extracted, phosphoric acid formed, from the rook. The higher the ocncentration of sulfurlc acld used, the more wash water neoded to ccmpletely wash the extracted phosphorus out of the unreacted rock. Using stolchlonetric amounts of sulfuric acid belcw $30 \mathrm{cme}$, rosulted in a decrease in the anount of phosphorus extracted. The optimum concentration of sulfuric acld for loaching of phosphate rock was $30^{\circ} \mathrm{Be} \cdot$

It was found essential for maximum extraction that the volume (In nil) of flltrete obtained be twice as great as the weight (in grams) of the residue. The weight of the residue obtained from all loachings was practloally constant being 5 to 10 per cent greater than the welght of the original rock used.

The concentration of phosphoric acid as obtalned from leaching was 5-10 per cent, but oould be increased to 25 per cent by evaporation of water. This phosphorlo acld could posibly be used for acidulation of phosphate rock to produce a phosphate fertilizer having a higher phosphorus content than ordinery superphosphate. The presence cf Iron and aluminum as lnpurities in the phosphoric aoid presented a jor problem ince both impuritie form insoluble phosphates that are unavaliable to plant ifo in fertilizers. Fusing phosphate rock th scolum carbonate and sodium hydroxide converted 25 per cent of the $\mathrm{P}_{2} \mathrm{O}_{5}$ in the rock to the water soluble form. The use of sodium chloride 
and sodium sulfate as fusing agents yiolded no water sclublo phosphato.

Leachings of phosphate rock were performed with sodium carbonate or sodium hydroxide sclution in maner similar to that used for sulfuric acid. These leachinga gave only small extractions of phosphorus from the rock. Defluorination of phosphate rook was carriod out wth two mods, crucible and flash roating. Both mothod. yiolded a phosphote rook contalning less than one per cent flucrino. Better results were obtalned in the cruelble mothod, in which the temperature used fe $1000^{\circ} \mathrm{C}$, in comparison with $750^{\circ} \mathrm{C}$ used in the flash roasting thod. Vnder comparablo temperature ccnditions, there was atrong indication of the superiority of the flash roating method. Thls method required a much ahorter reaction time than the cruclbie nethod. 
LITERATUE CITED 
(1) Groy, A. I., "Phosphatos and Superphosphates", p. 126, Lond on. Intersoleroe Publishors (1942).

(2) Fockstroth, J. T., Chem, and Ket. Eng*, 26, 77-79 (1922).

(3) Lar18on, E. L., Ind. Eng. Chem., 21, 1172-5 (1929).

(4) Klugh, B. G., Chem. and Not. Eng., 36, 666 (1928).

(5) Hignett, T. P., Chen. Eng. Frogress, 44,753-64, 821-32, 895-904 (1948).

(6) Jacob, K. D., Ind. Eng. Chem., 23, 14-21 (1931).

(7) Wansfiold, G. R., Ind. Eng. Chow., 34, 9 (1934).

(8) Uineral's Yearbook, 1945, Untted States Government Frinting office (1947) p: 1393.

(9) Meyer, Ernst Von, "A History of Chemistry", 3rd edition, p. 156. London, MeMilian and Co.. Itd. $(19610)$.

(10) Kirkpatr10k, S, D., Chem. and Het. Eng., 44, 644-9 (1937).

(11) Roscoe, H. E., and Sohorlemor, E., "A Treatise on Chemlatry". Vol. I, 4 th edition, p. 613, Lond on, Mckilian and Co., Lta. (1911).

(12) Carothors, J. N., Chem. Ind., 42, 523, 525, 527-8 (1938).

(13) Carothers, J. 1., J. Ind. Ene. Chem. 10, 35, 329 (1918).

(14) Carcthers, J. N., Ind. Bng* Chem., 9, 26 (1917).

(15) Wageaman, W. H., Easterwcod, H. W., and Turley, T. B., ए. S. Dept. Agr., Bul1. 1178, 53 pp. (1923).

(16) Weber, W. C., Shafer, R. W, and Roberts, I. J., J. S. Fatent To. 2, 049,032 (1936).

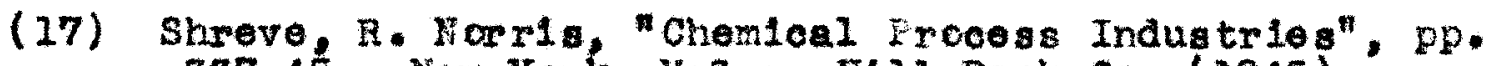
337-45. Now York, NeGraw-H11I Bock Co. (2945)."

(18) Curt18s, H. A., Trans. Am. Inst. Chem. Eng., 31, 278-95 (1935):

(19) Badger, W. L., and Baker, E. N., "Incrgante Chemical Technology", 2nd edition, pp. 127-33. New York, MOG raw-HI11 BOOK CO. (1941).

(20) Easterwood, H. W., Ind. Eng. Chem, 24, 8-19 (1942). 
(21) Hall, R. E., U. S. Patent No. 1,956,515 (1934).

(22) Frazer, H. F., Hoppe, T. C., Sullivan, J. H., and SmIth, E. R., Ind. Eng. Chem., 35, 1087-90 (1943).

(23) Fox, E. J., and Hill, W. L,, Ind. Eng. Cheme, 38, 329$34(1946)$.

(24) Elmore, K. L., U. S. Patent No. 2,368,649 (1945).

(25) Elmcre, K. I., Huffman, E. C., and Welf, W. W., Ind. Eng. Chom., 34, 40-48 (1942).

(26) Curtios, H. A. and N1Iler, A. H., Chem. and Met. Eng*, $43,408(1938)$.

(27) Curt1s8, H. A., M1ller, A, M,, and Junk1ng, Chemical and Net. Eng., 43, 583-87 (1936).

(28) Copson, R. L., Nevton, R. H., and Lindsay, J. D., Ind. Eng. Chem. 29, 175-9 (1937):

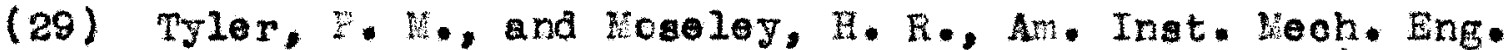
Teob. Publication No. 1053, kinine Technology (1939).

(30) Mller, A. Me, Mining and Met, 25, 492-4 (1924).

(31) Rogers, Allon, "Industrial Chemlatry", 4th odition, p. 503. Now York, D. Van Nostrand Co. (1925).

(32) Rloa, H., and Watson, T. L., "Eng Ineoring Geology", Sthedition, p. 123. Now York, John Wliey Sons, Ino. (1936).

(33) "Cfflolal and Tentative Wethods of Analyals of the Association of Cffielal Agrioultural chemist," 6 th edition, pp. 22-3. Washington, D. C., Asscelation Agrioulturel Chemist (1945).

(34) Boltz, D. F., and Kellon, $\mathrm{F}_{*}$ Q., Ind. Eng. Chem., Anal. Ed., 19, 673-77 (1947).

(35) Snel1, F. D., and Biffen, F. N., "Comerolal Wethode of Anal ys 1" " pp. 191-5, Now York, MoGraw-Hill Book Co., (1944).

(36) Willard, W. H., and Winter, O. D., Ind. Eng. Chom., Anal. Bd., 5, 7-10 (2933). 
51

A. ENDIX 


\section{ACKNOWLDONENT}

This rosearch was posible through a followahip grant from

the Univeraity of Louisville Inatitute of Industrial Researeh

as a portion of contracted research with the Foderal Chemical Compary 
$V I T A$ 
Stanloy Goldsmith, on of PhIlip and Lillian (Afte1) 0oldamith, was born in Norfolk, Virginia, Varoh 25, 1924. He attended Matthow Fontalne Maury High Sohool and after graduation in 1941 onrolled at the VIrginla Folytochnio Institute as a student of Chemical Engineering. He rooelved his Bacholor of Solence degreo in Chemieal Engineering in September, 1944, af ter whioh bo wa inducted into the Army. Wh110 in the Army he served with the Manhattan Distriot of Engineers on the Atomic Bcmb frojeet at Lcs Alamos, New Nex100. After serving 15 months in the Army ho was honorably discharged in February, 1946, and accopted a poltion at the UnIveralty of Callfornia's Los Alamos Laboratorios, where he obtained two yeara of industrial experienoo. Ho was granted a fellowshlp at tho speed seientific school of the University of Loulaville, and after performing research work under the sponsorship of the Institute of Industrial Research of the University of Loulsvilie, he reoelved the degroe of hater of Chemical Ingineering in March, 1049. 